\title{
1. What are international mass claims commissions?
}

International mass claims commissions (IMCCs) represent a unique and important form of international adjudication established to consider claims resulting from significant international war-related and traumatic historical events. ${ }^{1}$ Their principal, but not sole, aim is to determine compensation to individuals and states for certain losses, damages and injuries. $^{2}$

This chapter begins by analysing the common features of IMCCs. It then clarifies the differences between IMCCs and similar domestic and international mechanisms that may share some, but not all, of the characteristics of IMCCs. Finally, this chapter offers an historical overview of IMCCs and an initial introduction to the most relevant modern examples of IMCCs that form the core of this book's analysis.

We offer a detailed study of this important, though hitherto understudied, mechanism. Indeed, this book seeks to study analytically the fundamental procedural and substantive characteristics of IMCCs with the aim of providing a blueprint for future use.

\section{WHAT ARE IMCCS?}

IMCCs are ad hoc bodies and their structure, jurisdiction, procedure and ability to remedy vary considerably. Indeed, there is no uniform, formal definition of IMCCs. They make up an eclectic and unique group,

\footnotetext{
1 See, generally, Howard Holtzmann and Edda Kristjánsdóttir (eds), International Mass Claims Processes: Legal and Practical Perspectives (Oxford University Press, 2007). The book addresses such matters as funding, balancing arbitral and administrative approaches, key elements in drafting rules of procedure, establishing standards of proof, defining the respective functions of arbitrators and the secretariat and utilizing computer technology. See also David Caron, "International Claims and Compensation Bodies," in Cesare Romano, Karen Alter and Yuval Shany (eds), Oxford Handbook of International Adjudication (Oxford University Press, 2014).

2 For a detailed analysis of the reasons to create IMCCs, see Chapter 2.
} 
characterized by important shared characteristics. First, IMCCs are binding dispute resolution mechanisms; second, they are structured and act like judicial bodies; third, they are created after an event of international relevance; fourth, they are international law instruments; fifth, they engage the responsibility of states; and sixth, they are ad hoc institutions. Each of these elements is explored below.

\section{IMCCs Are Binding Dispute Resolution Mechanisms}

IMCCs are, first and foremost, binding dispute resolution instruments. Decisions made by international commissions are judicial decisions and are binding on all parties. IMCCs are not mediation or conciliation mechanisms, nor do they serve as advisory or review bodies. The instruments that create them typically contain a clause that makes their decisions binding on the relevant parties, who are, therefore, obligated under international law to respect and enforce them. The 2000 Algiers Agreement that created the Eritrea-Ethiopia Claims Commission (EECC), for example, states that decisions and awards of the commission are "final and binding" and that "the parties agree to honor all decisions and to pay any monetary awards rendered against them promptly." 3 Similar provisions exist in the instruments that created other IMCCs. ${ }^{4}$ By creating IMCCs, parties aim at providing final compensation to a defined set of legitimate claimants that have suffered harm. ${ }^{5}$

The fact that IMCCs are binding dispute resolution mechanisms does not, of course, mean that they are only binding dispute resolution mechanisms. Indeed, parties create international claims commissions for a variety of reasons. Thus, international claims commissions are also instruments that serve to transition from turmoil to peace. IMCCs are often part and parcel of a more comprehensive peace process. ${ }^{6}$ Parties also seek to have a third, neutral body deciding claims that are politically and domestically sensitive.

3 Art. 5 (17), Peace Agreement between Eritrea and Ethiopia, signed in Algiers on 12 December 2000, 13 December 2000, A/55/686 and S/2000/1183.

4 Art. IV of the Claims Settlement Declaration that created the Iran-US Claims Tribunals, for example, provides that "All decisions and awards of the Tribunal shall be final and binding." See also paras. 16-19 of UN Security Council Resolution 687 (1991) of 8 April 1991, UN Doc S/RES/687 (1991), that created the United Nations Compensation Commission.

5 See Chapter 4 for an analysis of who are the claimants and what are the different claims.

6 See Chapter 2 for a detailed discussion. 
Moreover, the creation of IMCCs generally also fulfills a variety of functions. In addition to providing satisfaction to parties involved through the payment of compensation and rectifying harms suffered by diverse groups, IMCCs provide a form of closure after a violent event. Often, they also help by providing a narrative and historical record for all the parties involved. ${ }^{7}$

\section{IMCCs Are Structured and Act as Judicial Bodies}

IMCCs are structured and act as judicial bodies, though each with its own variations. This is in direct correlation with the fact that they are binding dispute mechanisms, as explained above. Thus, IMCCs incorporate the essence of the principles of fair trials in their proceedings. They are neutral and impartial bodies, and decisions are taken by an odd number of independent and impartial adjudicators deciding by majority and in a timely fashion. ${ }^{8}$

Claims commissions are also structured to result in fair proceedings, where evidence can be presented equally by the parties and evaluated fairly by the tribunal. Thus, parties are usually represented by counsel. Proceedings most often include both a written and an oral phase, and hearings are open to the parties and their representatives, though they are most often held in camera. ${ }^{9}$

\section{IMCCs Are Created in the Aftermath of an International Upheaval}

IMCCs are created as a consequence of an underlying action or event involving at least two states that provoked a set of related claims, which the states themselves decided needed to be remedied. Historically, they have been created in the aftermath of an international violent upheaval, such as an armed conflict or a revolution, though the underlying event does not necessarily need to be violent.

Thus far, these events have included revolutions, like the 1979 Islamic Revolution in Iran, which overthrew the US-supported Shah and had significant economic repercussion for US businesses and US government contracts. They have also included wars, such as the 1998

\footnotetext{
7 See David Luban, Julie R. O'Sullivan and David P. Stewart, International and Transnational Criminal Law (Aspen, 2014).

8 For an analysis of the structure of the commissions and of the decision makers, see Chapter 3.

9 On the issue of evidence, see Chapter 6, on the issue of party representation see Chapter 5.
} 
Eritrea-Ethiopia war, which resulted in substantial loss of life, personal injuries and damages to property in both Eritrea and Ethiopia. Another event that resulted in the creation of an international claims commission was the territorial invasion of Kuwait by Iraq in 1991, which caused significant personal injuries and considerable damage to the property, environment, and natural resources of many states in the region.

The creation of an international claims commission mechanism is often also part and parcel of the peace process that all parties undertake to restore peace and trust after a significant crisis. IMCCs also aim to provide a form of closure and possible settlement between disputing parties who are often emerging from years of tense and violent relations.

\section{IMCCs Are Created by International Agreements}

IMCCs are international law bodies created by international agreement. The kind and format of each international instrument can vary substantially. For example, the Eritrea-Ethiopia Claims Commission was established by a bilateral agreement between Eritrea and Ethiopia, signed in 2000 and witnessed by the President of Algeria and the US Secretary of State. The United Nations Compensation Commission (UNCC) was created by a resolution of the UN Security Council in the aftermath of Iraq's invasion of Kuwait. ${ }^{10}$ The Iran-US Claims Tribunal was established through agreements expressed separately by Iran and the United States - which at the time did not have diplomatic relations - to the government of Algeria and collected in the Declaration of the Government of Algeria. ${ }^{11}$

Because they are international bodies, IMCCs also share many of the structural characteristics of international organizations: they are regulated under international law, they generally apply international law, and they employ mostly international staff.

The international nature of claims commissions is also important per se. In fact, in the aftermath of international turmoil, the involved parties often do not trust any party's domestic systems. They often seek a neutral and super partes entity that is capable of providing a venue for reconciliation and dialogue. An international setting offers these reassurances.

\footnotetext{
10 UNSC Res 687 (1991) of 8 April 1991.

11 Declaration of the Government of the Democratic and Popular Republic of Algeria Concerning the Settlement of Claims by the Government of the United States of America and the Government of the Islamic Republic of Iran (Claims Settlement Declaration), 19 January 1981.
} 


\section{IMCCs Engage the International Responsibility of States}

IMCCs engage the responsibility of the state as a sovereign entity and a subject of international law. Thus, they only engage the responsibility of states for violations of international law. This means that they only review claims for damages, loss and injuries to individuals, states and international organizations that result from an international wrongful act of a state, consisting of either an action or an omission, which constitutes a breach of an international obligation of the state itself and is attributable to the state under international law. ${ }^{12}$ Under the structure created by an IMCC's processes, states pay compensation to determined entities, which will usually include individuals and may also include other states, international organizations and private sector entities.

Importantly, IMCCs are not concerned with any criminal responsibility of individuals that could arise from the same events. Criminal responsibility is generally dealt with separately, through a separate and distinct process. In the aftermath of the Yugoslav conflict and the Rwanda genocide, for example, the Security Council created by its own resolutions the International Criminal Tribunal for Yugoslavia (ICTY) and the International Criminal Tribunal for Rwanda (ICTR). These international tribunals were tasked with prosecuting individuals for specific violations of international criminal law.

\section{IMCCs Are Ad Hoc Institutions}

Another important characteristic of IMCCs is their ad hoc nature. IMCCs are created for the specific purpose of resolving claims arising from a particular dispute or defined category of disputes. They are created after a violent event occurred and are dissolved after their functions are completed.

Thus, they are retrospective, backward-looking institutions with a docket that is fixed at the time of their creation. ${ }^{13}$ IMCCs are, therefore, also different from standing international courts, such as the International Court of Justice, which have a prospective and open docket, unknown to

12 See Articles 1 and 2 of the Draft Articles on the Responsibility of States for International Wrongful Acts, Text adopted by the International Law Commission at its 53rd session, 23 April - 1 June and 2 July-10 August 2001, and submitted as Official Records of the General Assembly, Fifty-sixth Session, Supplement No. 10, A/56/10.

13 See generally David Caron, "Towards A Political Theory of International Courts and Tribunals," (2007) 28 Berkeley Journal of International Law 401. 
the parties when they agree to submit themselves to the jurisdiction of those entities.

\section{THE UNIQUE NATURE OF IMCCS}

IMCCs are distinct and unique instruments in international law. However, there are several other international and domestic mechanisms that may share some of the characteristics or elements of IMCCs.

IMCCs, for instance, are different from domestic mass claims processes such as US class actions in the sense that they are ad hoc systems. IMCCs may also employ mass claims procedures but do not necessarily do so. For example, while some of the claims adjudicated by the UNCC used mass claims methodologies, neither the Iran-US Claims Tribunal nor the EECC have availed themselves of such procedures.

This book focuses only on IMCCs. The section below distinguishes IMCCs from other possibly similar instruments, namely mixed claims commissions, domestic claims processes, international criminal courts and tribunals, and truth and reconciliation commissions.

\section{IMCCs and Mixed Claims Commissions}

IMCCs share many of the characteristics of mixed claims commissions. Mixed claims commissions are ad hoc bodies created by an international agreement after an international conflict or internal disturbance, with the aim of settling claims between nationals of different states, between nationals of one state and the other state or between states themselves. ${ }^{14}$ Mixed claims commissions engage in formal proceedings, and their decisions are final and binding.

Unlike international claims commissions, mixed claims commissions only include commissions created by the states involved and created by treaties between states (generally treaties relating to arbitration and conciliation). Thus, mixed claims commissions do not include commissions set up by international organizations, such as the UNCC, which was created by a resolution of the United Nations Security Council. Mixed claims commissions represent, therefore, a subset of IMCCs.

14 Rudolf Dolzer, “Mixed Claims Commissions," Max Planck Encyclopedia of Public International Law, (Oxford University Press, last updated May 2011). 


\section{IMCCs and Domestic Claims Processes}

IMCCs differ also from compensation mechanisms established by one state only, even those established on the basis of an international agreement. Indeed, domestic compensation mechanisms are numerous. In the United States, for example, the Foreign Claims Settlement Commission (FCSC), an agency of the Department of Justice, settles claims that US nationals have against foreign governments. The jurisdiction of the FCSC is conferred by Congress, through an international claims settlement agreement or at the request of the secretary of state. Its funds derive from either Congressional appropriations, international claims settlements or from liquidation of foreign assets in the United States. Completed FCSC claims programs include claims against the Federal Republic of Germany, Bulgaria, Romania, Poland and Albania. ${ }^{15}$ Although international in origin, these claims are fully addressed and resolved in the domestic context by a US governmental agency.

Claims commissions are also established to deal with wholly domestic events. For example, in the aftermath of the 2010 Deepwater Horizon oil spill in the Gulf of Mexico, British Petroleum, which owned the damaged oil rig, established the Gulf Coast Claims Facility (GCCF), a \$20 billion fund to settle claims for natural resource damages, state and local response costs, and individual compensation arising from the oil spill. These are entirely domestic claims that may use mass claims procedures but share little else with IMCCs.

\section{IMCCs and International Criminal Courts and Tribunals}

IMCCs only engage the responsibility of states for violations of international law as a sovereign entity and a subject of international law. IMCCs do not adjudicate criminal responsibility of individuals that may arise from the same events.

In recent years, separate international ad hoc mechanisms have been established by the international community to deal with criminal responsibility. For example, the ICTR and the ICTY were set up by the UN Security Council to judge those individuals most responsible for gross violations of international criminal law, including the crime of genocide, crimes against humanity, war crimes and grave breaches of the Geneva

15 For more on the Foreign Claims Settlement Commission, see https:// www.justice.gov/fcsc. In addition, Chapter 3 touches on the role of the FCSC in resolving a subset of claims settled and outsourced to it by the Iran-US Claims Tribunal. 
Conventions, which establish basic principles of international humanitarian law. The ICTY and ICTR could impose prison terms, up to life imprisonment, on those found guilty. Their jurisdiction was limited to individuals only and did not include any review of acts of states. Further, neither the ICTY nor the ICTR provided any monetary compensation to victims.

At times, these mechanisms are created in parallel with other claims commissions, but remain separate. For instance, several real-property claims processes ran in parallel to the ICTY. These included the Commission for Real Property Claims of Displaced Persons and Refugees in Bosnia-Herzegovina (CRPC), established by the 1995 Dayton Peace Agreement. The CRPC was headquartered in Sarajevo and had a mixed composition of nine members: six internationals appointed by the President of the European Court of Human Rights, and six nationals, two appointed by the Republika Srpska and four appointed by the Federation of Bosnia and Herzegovina. The CRPC dealt only with mass property claims resulting from the disintegration of Yugoslavia. ${ }^{16}$

\section{IMCCs and Truth and Reconciliation Commissions}

International Truth and Reconciliation Commissions are typically created after a violent international or domestic event that significantly impacted a state. The fundamental functions of these commissions are to provide an instrument of reconciliation and closure to the parties involved, through a process of dialogue, and to create an historical record. IMCCs are adjudicative bodies and are therefore inherently different from Truth and Reconciliation Commissions.

The last few decades have seen the establishment of several International Truth and Reconciliation Commissions. For example, the government of South Africa created a Truth and Reconciliation Commission (TRC) after the abolition of apartheid. The TRC served largely as a reconciliation mechanism and created an important historical record of the abuses that occurred during apartheid. Hearings were mostly held in public and were often televised. Witnesses who were identified as victims of gross human rights violations were invited to give statements about

16 Hans van Houtte, "Mass Property Claim Resolution in a Post-War Society: The Commission for Real Property Claims in Bosnia and Herzegovina" (1999) 48 International and Comparative Law Quarterly 625-638. The operational structure of the CRPC is discussed in more detail in the second section of Chapter 3. 
their experiences. At the same time, perpetrators could also give testimony and ask for amnesty from both civil and criminal prosecution. This served an important, cathartic function and also helped to create a record and historical narrative.

Similarly, Argentina created the National Commission on the Disappearance of Persons after the Dirty War and the military dictatorship that ruled Argentina from 1976 to 1983. This Commission documented human rights violations committed during that period and established an important record. The work of the Commission also resulted in the trial of some of the military commanders for war crimes. Similar commissions were established in Uganda, Guatemala, El Salvador and the Philippines, among other places.

\section{CLAIMS COMMISSIONS IN HISTORY}

The history of IMCCs is rooted in post-conflict compensation mechanisms, and their subsequent development altered the presumption that their only useful function was to extract compensation from the vanquished to the victors for war damages. ${ }^{17}$ As such, IMCCs largely replaced arbitration by single persons (generally a head of state) and mixed arbitral tribunals, and they introduced judicial elements in the resolution of the dispute, in terms of procedure, due process and the right of all parties to be heard.

This section looks at international claims commissions from an historical perspective. It first offers a short exploration of past claims commissions and then examines the contemporary model of IMCCs.

\section{An Overview of Past Claims Commissions}

Historically, IMCCs saw their first iteration in the 1794 Jay Treaty between the United States and the United Kingdom, which established two commissions to resolve claims of British merchants against the United States and those of US ship-owners against the UK. ${ }^{18}$

In the nineteenth and twentieth centuries, claims commissions became a leading method of peaceful settlement of international disputes. Indeed, in that period, affected states created more than 90 claims commissions after wars or revolutions in order to decide claims arising from either

\footnotetext{
17 Dolzer, "Mixed Claims Commissions."

18 Treaty of Amity, Commerce, and Navigation, Between His Britannic Majesty and the United States of America, 1794 (Jay Treaty).
} 
international or domestic conflict during which aliens suffered damages. ${ }^{19}$ For example, claims commissions were created to settle claims against France after the Napoleonic Wars. Claims commissions were also established in 1839, 1854, 1859 and 1868 (after Mexico's independence) to settle claims between the United States and Mexico over territory and taxation, as well as claims from private citizens. Claims settlements commissions were established in many instances in Latin America, including in Chile, Venezuela and Peru. For example, the 1903 joint commission between Panama and the United States was created to compensate property claims arising out of the establishment of the Panama Canal. ${ }^{20}$ The commission was composed of four members, two appointed by the President of the United States and two appointed by the President of Panama. In case of disagreement of the commission, an umpire was appointed by the two governments to render a final decision. $^{21}$

Claims commissions were also created to decide damages arising out of World War I. The Treaty of Versailles, which ended the war, provided for the creation of a reparations commission to establish the amount Germany would be required to pay France, the United Kingdom and the other Allied Powers. Additionally, the United States negotiated a separate reparation agreement in the Treaty of Berlin, which established a Mixed Claims Commission to provide compensation for both sovereign and, importantly, individual claims. A similar agreement was reached by the United States with Austria and Hungary through the Tripartite Claim Commission.

An additional set of claims commissions was set up between the United States and Mexico to deal with longstanding claims. The American-Mexican Claims Commission (the General Commission) was created by treaty to adjudicate claims by US and Mexican citizens for losses suffered due to the acts of one government against nationals of the other. It lasted from 1924 to 1934. A Special Commission was also created by the two countries to resolve claims pertaining to the Mexican Revolution. The commissions were not entirely successful, but Mexico and the United States eventually settled all claims in 1934.

The use of mixed claims commissions declined after World War II, as countries were wary of the effects that payment of heavy reparations had

19 C. Romano, "A Taxonomy of International Rule of Law Institutions" (2011) 2 Journal of International Dispute Settlement 264.

20 Convention Between the US and Panama (Panama Canal), 1903, see especially Arts. VI and XV.

21 See Dolzer, "Mixed Claims Commissions." 
had on Germany: The substantial reparations provided in the Treaty of Versailles were seen as one of the indirect causes of World War II. Reparations after World War II were negotiated bilaterally with Germany, and no general claims commission was established. ${ }^{22}$

\section{Contemporary IMCCs}

Up until the latter half of the twentieth century, most agreements establishing mixed claims commissions were concluded between the United States, on one side, and either Latin American or European states on the other or among European states. Asia, Africa and the Middle East were largely absent and did not use this mechanism. ${ }^{23}$

The resurgence of the claims commission mechanisms occurred with the establishment of the Iran-US Claims Tribunal in 1981, followed by the United Nations Compensations Commission in 1991, and the EritreaEthiopia Claims Commission in 2000. Each entity is briefly described below.

The development of modern IMCCs, which are the focus of this book, clearly drew from the experience of the past. The essence of the post-conflict dispute resolution mechanisms was maintained, while new judicial elements were introduced. Contemporary claims commissions also involved a much larger variety of regional actors.

\section{The Iran-US Claims Tribunal}

The Iran-US Claims Tribunal is the first modern example of an international claims adjudication program. ${ }^{24}$ It was created in 1981, through indirect negotiations between Iran and the United States, to adjudicate individually complex commercial and international law cases totaling tens of billions of dollars. Despite a challenging mandate and a tense

22 Dolzer indicates three bilateral claims commissions: the Arbitral Commission on Property, Rights and Interests in Germany; the Conciliation Commissions Established Pursuant to Art. 83 Peace Treaty with Italy (1947) and the Property Commissions Established Pursuant to Art. 15 Peace Treaty with Japan (1951).

23 See Dolzer, "Mixed Claims Commissions."

24 For an excellent overview, see Jeremy K. Sharpe, "The Iran-United States Claims Tribunals," in C. Giorgetti (ed.), The Rules, Practice and Jurisprudence of International Courts and Tribunals (Martinus Nijhoff Publishers, 2012). See also Richard Lillich (ed.), Iran-United States Claims Tribunal 1981-1983 (Charlottesville, VA: UP of Virginia, 1985). 
political climate, the Iran-US Claims Tribunal has successfully resolved over 3,900 claims and is still hearing cases in The Hague. ${ }^{25}$

The creation of the Iran-US Claims Tribunal was part of the settlement of the hostage crisis that followed the Islamic Revolution in Iran, which culminated in 1979 with the ousting of the Shah and the establishment of the Islamic Republic of Iran. In the period leading to the crisis, the United States was a key ally to the Shah and had provided critical support to his regime through trade, investment and military equipment. The decline in popular support for the regime of the Shah resulted in rising anti-American sentiment. In early 1979, the Shah left Iran and the government of his successor, Ayatollah Ruhollah Khomeini, began a nationalization process that included the banking, insurance and oil sectors. US nationals in Iran faced increasing difficulties, and, by the summer, around 45,000 Americans living in Iran had fled the country. On 4 November 1979, the situation further deteriorated when a group of Iranian militants seized the US Embassy in Tehran and detained a number of diplomats and consular officers.

As it became clear that the militants enjoyed the support of the new Iranian government, the United States responded by taking a series of retaliatory actions, including severing diplomatic relations, imposing economic sanctions and freezing Iranian assets held in the United States. Following Iraq's unexpected invasion of Iran in 1980, Algeria acted as a broker and mediator to resolve the deadlocked situation and negotiate a peace agreement. On 19 January 1981, the Algerian government issued two declarations (known as the Algiers Accords), one signed with Iran and one signed with the United States, which was composed of several documents containing legally binding provisions. ${ }^{26}$ The General Declaration contains the main commitments of the parties, including the liberation of the US hostages, the transfer of some frozen assets back to Iran and the termination of litigation in the US courts in favor of arbitration. The Claims Settlement Declaration established the Iran-US Claims Tribunal, headquartered in The Hague.

The Iran-US Claims Tribunal is still operating as an independent arbitral body and is composed of nine judges: three from the United States, three Iranians and three judges (including the President) from other countries appointed by the party-appointed members (or, if they

25 For more information, see the Tribunal website at: https://www.iusct.net/ Pages/Public/A-About.aspx.

26 The Algiers Accords, including the General Declaration, are available at: http://www.iusct.net/General\%20Documents/1-General\%20Declaration\%E2\%80 $\% 8$ E.pdf. 
cannot agree, by the Tribunal's appointing authority). The Tribunal decides cases by majority of either one of the three member Chambers or by the full Tribunal. Article V of the Claims Settlement Declaration provides that the Tribunal shall "decide all cases on the basis of respect for law, applying such choice-of-law rules and principles of commercial and international law as the Tribunal determines to be applicable, taking into account relevant usages from the trade, contract provisions and changed circumstances."27

The jurisdiction of the Tribunal includes private claims of US nationals against Iran and of Iranian nationals against the United States arising out of debts, contracts, expropriations or other measures that affected property rights. Claims under $\$ 250,000$ are defined as small claims. About 2,800 small claims were filed (the great majority from US nationals), and they were settled by a lump-sum payment by Iran to the United States of $\$ 105$ million. About 1,000 large claims were filed and decided by 2003 . Overall, the Iran-US Claims Tribunal has awarded more than $\$ 2.5$ billion to US nationals and companies. ${ }^{28}$ The Iran-US Claims Tribunal also has jurisdiction over official claims between Iran and the United States based on contractual arrangements for the purchase and sale of goods and services. Washington has filed 24 cases and Tehran has filed 53 cases. Seventy-two of those claims have been decided. The remaining pending cases are all by Iran against the United States.

In its procedures, the Tribunal uses the arbitration rules of the United Nations Commission on International Trade Law (UNCITRAL), as modified by the parties and the Tribunal. The cost of running the Tribunal is split equally between the two parties. Under the Algiers Accord, Iran agreed to place $\$ 1$ billion in an account as security for payment of Iran-US Claims Tribunal awards against Iran, and to keep that account at $\$ 500$ million until all awards against Iran are satisfied. This unique mechanism simplifies the enforcement of awards and makes payments possible. $^{29}$

The Iran-US Claims Tribunal is the longest-running international commission in history and has many achievements. Despite the persistence of a tense relationship between Iran and the United States, the Tribunal has resolved by binding arbitration the great majority of the disputes that it was mandated to resolve. The awards have been respected

27 Art. 5 Claims Settlement Declaration, available at: http://www.iusct.net/ General\%20Documents/2-Claims\%20Settlement\%20Declaration.pdf.

28 See the overview of the tribunal by US State Department, available at: http://www.state.gov/s/1/3199.htm.

29 A general discussion of remedies and compliance is found in Chapter 7. 
and enforced, although its slow pace and the difficult relations between Iran and the United States have impacted the work of the Tribunal. ${ }^{30}$ However, the Iran-US Claims Tribunal remains an example of a successful international claims commission. It also sets a useful example for the creation of future IMCCs and provides initial guidance for possible structure and procedure of future similar mechanisms.

\section{The United Nations Compensation Commission}

In the wake of the successful creation of the Iran-US Claims Tribunal, the United Nations decided to create a compensation commission to process and pay claims compensation for a variety of losses resulting from Iraq's invasion of Kuwait in August 1990. The task was monumental: between 1991 and 2005, the commission processed about 2.7 million claims seeking more than $\$ 350$ billion in compensation. ${ }^{31}$

As with other IMCCs, the roots of the creation of the United Nations Compensation Commission (UNCC) are found in a violent international event. On 2 August 1990, Iraq invaded Kuwait and started a seven-month occupation of the country. The invasion and occupation caused great destruction to property and natural resources, resulted in the death and injury of thousands of Kuwaitis and foreign civilians and some 300,000 foreign workers fled Kuwait. A UN-sanctioned military intervention led by the United States deployed in January and February 1991 to reverse the occupation. Memorably, Iraqi troops set alight more than 600 Kuwaiti oil wells when leaving the country, causing enormous environmental and economic damage.

The UNCC was created in the aftermath of Iraq's invasion as a subsidiary organ of the UN Security Council by Resolution 687 of the Security Council. The Resolution contained the basic framework for the establishment and the jurisdiction of the UNCC, providing that, as a

30 See Lee Caplan, "Challenges of Arbitrators in the Iran-US Claims Tribunals," in C. Giorgetti (ed.), Challenges and Recusals of Judges and Arbitrators in International Courts and Tribunals (Brill, 2015), see also Sharpe, "The Iran-United States Claims Tribunals."

31 For an overview of the UNCC, see David Bederman, "The United Nations Compensation Commission and the Tradition of International Claims Settlement" (1994) 27 New York University Journal of International Law and Politics 1-42. See also Timothy J. Feighery, "The United Nations Compensation Commission," in C. Giorgetti (ed.), The Rules, Practice and Jurisprudence of International Courts and Tribunal (Martinus Nijhoff Publishers, 2012) and Timothy J. Feighery, Christopher S. Gibson and Trevor M. Rajah (eds), War Reparations and the UN Compensation Commission - Designing Compensation After Conflict (Oxford University Press, 2015). 
result of its unlawful invasion and occupation of Kuwait, Iraq was "liable under international law for any direct loss, damage, including environmental damage and the depletion of natural resources, or injury to foreign Governments, nationals and corporations." 32 It also created a special Fund to be financed by a percentage of the value of Iraq's petroleum and petroleum-products exports. The Fund permitted the payments of all the claims and covered all the cost of the UNCC. ${ }^{33}$

The UNCC was given unusually extensive jurisdiction, which included claims for individuals who were forced to leave Iraq or Kuwait as a result of the invasion, individual claims for serious personal injury or death, and individual claims for losses. This jurisdiction also included claims by corporations and other private or public enterprises, claims from governments in the region (including Iran, Saudi Arabia, Syria, Jordan and Kuwait) and international organizations. ${ }^{34}$ Overall, about 2.7 million claims were filed with the Commission, with an asserted value of $\$ 352.5$ billion. The Commission concluded the processing of claims in 2005 . Out of the claims filed, it awarded compensation of about $\$ 52.4$ billion to approximately 1.5 million successful claimants. ${ }^{35}$ The UNCC has so far paid $\$ 47.8$ billion in compensation. The remaining amount of $\$ 4.6$ billion pertains to a single claim awarded to Kuwait for the production and revenue losses resulting from damages to Kuwait's oil-fields assets.

The administration of such a vast program required the establishment of a large administrative structure, which was comprised of three organs. ${ }^{36}$ The Governing Council, whose membership mirrored that of the Security Council, was the principal organ responsible for the general policy and legal framework. It also reviewed and finally approved the reports and recommendations on claims made by the commissioners. The commissioners, nominated by the UN Secretary-General upon recommendation of the executive secretary of the UNCC, sat in panels of three members to consider and render recommendations on claims in specific categories. Finally, the Secretariat, headed by the executive secretary, supported the work of both the Governing Council and the commissioners. The Secretariat was headquartered in Geneva, Switzerland, and, at its peak, numbered 250 staff.

32 UNSC Res 687 (1991) of 8 April 1991, UN Doc S/Res/687.

33 See also UNSC Res 692 (1991) detailing the funding procedures. Issues of funding and costs are discussed in depth in Chapter 7.

34 For a detailed explanation of the kinds of claims received as well as an analysis of the claimants, see Chapter 5 .

35 For specific awards, see the website of the UNCC at: http://www.uncc.ch.

36 For a general discussion of the structures of IMCCs, see Chapter 3. 
The legacy of the UNCC is substantial, and it processed a large number of claims in a relatively short time. It was the first example of a successful mass claims procedure that provided compensation on a priority basis to thousands of foreign workers who had to flee the region. The UNCC was, however, very much objected to by Iraq, which saw it as an unreasonable imposition by the international community. ${ }^{37}$ This remained true until 2003, when a US-led coalition invaded Iraq and deposed Saddam Hussein. The new coalition-backed government collaborated more with the UNCC. This period of greater cooperation coincided with the resolution of larger and more complex claims. Iraq had more extensive access to counsel and decisions were taken after all parties were heard. Certainly, claims processing was facilitated by the fact that Iraq's liability for losses was already established in Resolution 687 and the creation of the fund for the payment of awards. Still, the professionalism and hard work of the UNCC allowed for the mostly smooth administration of a complex situation.

\section{The Eritrea-Ethiopia Claims Commission}

The most recent example of an international claims commission is the Eritrea-Ethiopia Claims Commission (EECC), created in 2000 as part of the peace agreement between the two countries. The EECC closely resembled an international tribunal, though it was tasked with administering claims arising from the violation of international law, including humanitarian law, by Eritrea and Ethiopia. ${ }^{38}$

Between 1998 and 2000, Eritrea and Ethiopia fought a ruinous boundary war that resulted in a significant loss of life, personal injury and economic damage. Approximately 70,000 combatants died, and 35,000 people were displaced by the war. The conflict ended in June 2000, thanks to a ceasefire agreement negotiated with the assistance of the United Nations, the Organization of African Unity (OAU) (now, the African Union), the United States and others, which was signed in Algiers. ${ }^{39}$ The agreement was followed by a permanent peace agreement,

37 See Michael E. Schneider, "The Role of Iraq in the UNCC Process with Special Emphasis on the Environmental Claims," in Timothy J. Feighery, Christopher S. Gibson and Trevor M. Rajah (eds), War Reparations and the UN Compensation Commission - Designing Compensation After Conflict (Oxford University Press, 2015).

38 See, generally, Sean D. Murphy, Won Kidane and Thomas R. Snider, Litigating War: Mass Civil Injury and the Eritrea-Ethiopia Claims Commission (Oxford University Press 2013).

39 Agreement on Cessation of Hostilities, signed in Algiers on 18 June 2000. 
also signed in Algiers, on 12 December 2000. The agreement terminated the hostilities between the two countries and established a neutral Boundary Commission to delimit and demarcate the borders between Eritrea and Ethiopia. ${ }^{40}$ Article 5 of the Agreement also established a Claims Commission to decide "through binding arbitration all claims for loss, damage or injury by one Government against the other and by nationals (including both natural and judicial persons) of one of the parties against the Government of the other party or entities owned or controlled by the other party" that were related to the conflict and resulted "from violations of international humanitarian law, including the 1949 Geneva Conventions, or other violations of international law." 41

The EECC was established under the auspices of the Permanent Court of Arbitration (PCA), which served as its registry, maintained the Commission's files and managed communications between the Commission and the parties. The EECC used the staff of the PCA on a part-time basis instead of retaining its own staff. The EECC consisted of five commissioners: Eritrea and Ethiopia appointed two commissioners each. The fifth, the presiding commissioner, was selected by the four partyappointed commissioners. The Algiers Agreement mandated the EECC to adopt its own rules of procedure based on the 1992 PCA Arbitration Operational Rules for Arbitration Disputes Between Two States. After consultation with the parties, the Commission adopted its Rules of Procedure in October 2001. The parties agreed to split the costs of the Commission equally. The Commission was based in The Hague and could at its discretion hold hearings and conduct investigations in the territory of the parties or in any other location as it deemed appropriate. Under the Algiers Agreement, claims had to be filed by 12 December 2001 (one year after the signing of the Agreement). The Commission was instructed to attempt to finalize proceedings within three years after the claims-filing period, though the deadline was extended and the final decision was issued in 2009.

The EECC issued its first decisions on jurisdiction and procedure in 2001, several partial awards on the merits from 2003 to 2005, and final awards on damages in August 2009. Decisions were required to be made by majority, but were, in almost all cases, made unanimously. In its partial awards, the EECC dealt with a variety of issues, including the

40 Agreement between the Government of the State of Eritrea and the Government of the Federal Democratic Republic of Ethiopia, 12 December 2000, transmitted to the Secretary General of the United Nations and President of the Security Council as UN Doc A/55/686 and S/2000/1183.

41 Art. 5, Algiers Agreement. 
treatment of prisoners of war, internees and civilians, the legality of certain means and methods of warfare, the treatment of diplomatic premises and personnel, and the looting, seizure and unlawful destruction of private property. The damage awards ordered the payment of compensation of about $\$ 161$ million to Eritrea and about \$2 million to Eritrean nationals. The EECC awarded about $\$ 174$ million to Ethiopia.

The EECC's accomplishments are significant. The Commission was tasked with the assessment of very complex and delicate claims originating from the law of war. It did so carefully and expeditiously. The work of the Commission also contributed to the maintenance of the peace between Eritrea and Ethiopia, as the two parties - though still in a tense relationship - have not since resumed the conflict.

Still, the EECC was not immune from criticism. The most controversial act was its decision to issue an award on jus ad bellum, which it found Eritrea had violated. ${ }^{42}$ This decision was criticized as overstepping the Commission's mandate because Article 3 of the Algiers Agreement provided for the investigation of the origins of the conflict by an independent and impartial body to be appointed by the Secretary-General of the OAU, in consultation with the Secretary-General of the UN and the two parties. ${ }^{43}$ Not surprisingly, once the Claims Commission purported to resolve the issue, the OAU body was never brought into existence. Additionally, the awards have yet to be paid, though neither party is adamantly demanding payment, which substantially undermines the very reason for creation of the Commission. The situation is vastly complicated by the refusal of one of the parties (Ethiopia) to adhere to the decision made by the Boundary Commission - it also was, by the Algiers Agreement, declared to be "final and binding".

\section{Other international compensation commissions}

Other modern international compensation commissions include:

Commission for real property claims of displaced persons and refugees in Bosnia-Herzegovina (CRPC) The CRPC was established by the General Framework Agreement for Peace in Bosnia-Herzegovina and the former Republic of Yugoslavia (the Dayton Accord). Its purpose was adjudication of individual claims to property or occupancy rights after the

42 EECC, Partial Award - Jus Ad Bellum - Ethiopia's Claims 1-8, issued on 28 April 2004.

43 Christine Gray, "The Eritrea/Ethiopia Claims Commission Oversteps Its Boundaries: A Partial Award?" (2006) 17 European Journal of International Law 699. 
armed conflict in Yugoslavia, which had resulted in an estimated 2.2 million refugees and displaced persons. ${ }^{44}$ The CRPC was headquartered in Sarajevo and at one point had 320 staff members. It had a mixed composition of nine members: six internationals appointed by the President of the European Court of Human Rights; and six nationals, two appointed by the Republika Srpska and four appointed by the Federation of Bosnia and Herzegovina. The CRPC dealt only with property claims resulting from the disintegration of Yugoslavia. ${ }^{45}$ Indeed, it was created to ensure legally binding decisions to guarantee the rights of those who had lost property during the conflict by either enabling them to return home or to receive compensation for their loss. ${ }^{46}$ The decisions of the commission were reviewed by the Supreme Court of Kosovo or another competent court. Remedies available included eviction, placing the property under administration, auction and compensation. The CRPC operated for seven years. It heard nearly 300,000 claims, benefitting an estimated one million people. ${ }^{47}$ It was funded mostly by contributions from the European Union and the United States. ${ }^{48}$

Housing and Property Claims Commission (HPCC) The HPCC was established, like the CRPC, in part of the former Yugoslavia for the purpose of adjudicating individual claims to property or occupancy rights in the wake of armed conflict. ${ }^{49}$ The HPCC was created by regulation 1999/23 of the United Nations Interim Administration Mission in Kosovo (UNMIK), which at the time administered Kosovo. ${ }^{50}$ The HPCC was given exclusive jurisdiction to "settle private non-commercial residential property disputes" until the Special Representative of the UN SecretaryGeneral in Kosovo, who headed UNMIK, determined that local courts

44 Article VII of Annex 7, Bosnia and Herzegovina-Croatia-Yugoslavia: General Framework Agreement for Peace in Bosnia and Herzegovina Ann. 7 art. VII, Dec. 14, 1995, 35 ILM 75, 139.

45 van Houtte, "Mass Property Claim Resolution in a Post-War Society."

46 van Houtte, "Mass Property Claim Resolution in a Post-War Society," 91. Claimants did not have to establish that the alleged dispossession was caused by the conflict; Dayton Accord, Art. XI.

47 See Commission or Real Property Claims of Displaced Persons and Refugees, End of Mandate Report (1996-2003), available at: http://www.pictpcti.org/publications/Bibliographies/EMR-Part1-CoverExec1-Summary-EMR.pdf.

48 CRPC, End of Mandate Report.

49 Reparation Mechanisms at 89.

50 On the Establishment of the Housing and Property Directorate and the Housing and Property Claims Commission, UNMIK Reg. No. 1999/23, UNMIK, $\S 2$, UN Doc UNMIK/REG/1999/23 (1999). 
could carry out the same mandate. The Commission was composed of three members, two of whom, including the chair, were international staff, and one is a national of Kosovo. It acted as a mass claims processing mechanism. ${ }^{51}$ The HPCC was originally given jurisdiction over three types of claims: "claims by natural persons (a) whose rights to residential real property were revoked on the basis of discriminatory legislation, (b) who entered into informal transactions of residential property after 23 March 1999, or (c) who owned property prior to March 24, 1999 and involuntarily lost possession of the property." ${ }^{52}$ It was replaced in March 2006 by the Property Claims Commission (PCC), ${ }^{53}$ which has operated since December 2008 under a law passed by the Assembly of Kosovo. ${ }^{54}$ UNMIK Regulation 2006/10 on the "Resolution of Claims Relating to Private Immoveable Property, including Agricultural and Commercial Property" (as amended) mandated the PCC to resolve "conflict-related claims resulting from the armed conflict that occurred between 27 February 1998 and 20 June 1999," including ownership claims and claims involving property use rights with respect to private immoveable property including agricultural and commercial property, where the claimant is not able exercise those rights. ${ }^{55}$ The deadline for receiving claims expired on 3 December 2007. Claims filed since that date fall within the jurisdiction of Kosovo domestic courts. ${ }^{56}$ During its work, the commission heard more than 29,000 claims.

Holocaust claims Holocaust claims refer to the collection of claims arising from the Holocaust committed by Germany during the Nazi regime. It includes claims of restitution of funds and compensation from,

51 See http://www.kpaonline.org/kpcc.asp.

52 UNMIK Reg. No. 1999/23, § 1.2(a)-(c).

53 Final Report of the Housing and Property Claims Commission, Housing and Property Claims Commission 9, 30 n97 (2007), available at: http://www.pcacpa.org/showfile.asp?fil_id=626. Resolution 2006/10 established the Kosovo Property Agency (KPA), which consisted of a Supervisory Board, Executive Secretariat, and a Property Claims Commission (PCC). UNMIK, Reg. No. 2006/10, § 3 .

54 Reparation Mechanisms, 90; Amending UNMIK Reg. 2006/50 on the Resolution of Claims Relating to Private Immovable Property, Including Agricultural \& Commercial Property (Law No. 03/L-079) (Kos.).

55 On the Resolution of Claims Relating to Private Immovable Property, Including Agricultural and Commercial Property, UNMIK/REG/2006/10 of 4 March 2006, UN Doc. UNMIK/REG/2006/10 (2006) available at: http:// www.kpaonline.org/hpd/pdf/UNMIK\%20Regulation\%202006-10\%20(2).pdf.

56 Reparation Mechanisms, 92-93. 
among others, Swiss banks for money held in accounts, life insurance claims that were in place before the Holocaust and from German corporations that benefited from the forced slave labor of the Holocaust victims. ${ }^{57}$

\section{CONCLUSION}

This chapter introduces IMCCs as a unique and important form of international adjudication, established to consider claims resulting from significant international war-related and traumatic historical events. IMCCs are an eclectic group but share important characteristics. This chapter provides an analysis of these characteristics, as well as a brief historical overview of the main IMCCs. In the following chapters, we focus our attention on three commissions: the Iran-US Claims Tribunal, the United Nations Compensation Commission, and the Eritrea-Ethiopia Claims Commission.

The resurgence of IMCCs comes in conjunction with the acceptance of the need to adjudicate claims related to armed conflicts. It is increasingly becoming the norm that in post-conflict societies, individual remedies can contribute to a lasting peace. Indeed, an international dispute resolution body created with the active participation of all relevant parties can create a solution seen as building trust between adversaries and ensuring the compensation of innocent victims.

The creation of a heterogeneous system of claims commissions also complements the proliferation of international courts and tribunals as one

57 The resolution of Holocaust claims includes a complex system of claims commissions including: Austrian General Settlement Fund; Austrian Fund for Reconciliation, Peace and Cooperation; Belgian Jewish Community Indemnification Commission; Claims Resolution Tribunal (CRT I \& II); French Commission for the Compensation of Victims of Spoliation Resulting from the Anti-Semitic Legislation in force during the Occupation; German Forced Labor Compensation Program (GFLCP); German Foundation "Remembrance, Responsibility and Future"; Holocaust Victim Assets Program (HVAP); The International Commission on Holocaust Era Insurance Claims (ICHEIC); The Netherlands' Foundation for Individual Bank Claims Shoah; The Netherlands' Holocaust Foundation for Individual Insurance Claims; The Netherlands' Shoah Foundation for Individual Securities Claims and the Conference on Jewish Material Claims Against Germany. Each of these institutions addressed a specific type or category of claim. See PCA website, Mass Claims Processes Relating to the Holocaust, at: https://pca-cpa.org/en/services/arbitration-services/mass-claims-processes/. (The most important Holocaust claims are the CRT I \& II). 
further option for post-conflict reparations. Other mechanisms include truth and reconciliation commissions and domestic proceedings.

The chapters that follow critically assess the main constitutive and procedural characteristics of claims commissions and highlight lessons learned from past practice. 